\title{
CNTRL/FGFR1 Fusion Gene
}

National Cancer Institute

\section{Source}

National Cancer Institute. CNTRL/FGFR1 Fusion Gene. NCI Thesaurus. Code C99698.

A fusion gene that results from a chromosomal translocation $t(8 ; 9)(p 12 ; q 33)$ which fuses exon 15 of the CNTRL gene with exon 8 of the FGFR1 gene. This translocation is associated with 8p11 myeloproliferative syndrome. 